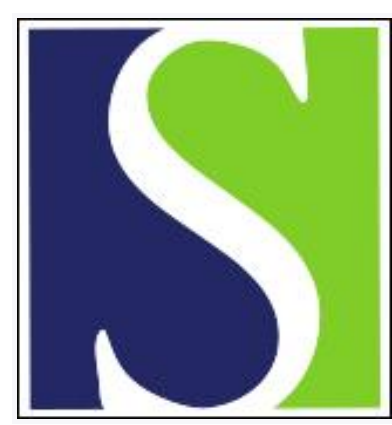

Scand J Work Environ Health 1977;3(3):144-153

https://doi.org/10.5271/sjweh.2779

Issue date: Sep 1977

\title{
Concrete work and myocardial infarction.
}

by Theorell T, Olsson A, Engholm G

The following article refers to this text: $2020 ; 46(1): 1-4$

Key terms: concrete work; mortaility; myocardial infarction; physical effort; psychological stress; stress

This article in PubMed: www.ncbi.nlm.nih.gov/pubmed/910124

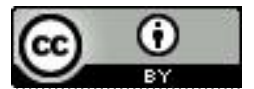




\title{
Concrete work and myocardial infarction
}

\author{
by TÖRES THEORELL, M.D. ${ }^{1}$, ALICE OLSSON, B.Sc. ${ }^{2}$, and GÖRAN ENGHOLM, B.Sc. ${ }^{3}$
}

\begin{abstract}
THEORELL, T., OLSSON, A. and ENGHOLM, G. Concrete work and myocardial infarction. Scand. j. work environ. \& health 3 (1977) 144-153. A total of 8,973 male building construction workers 41 to 61 years of age in greater Stockholm were asked to participate in a psychosocial questionnaire study. A two-year follow-up study of myocardial infarctions was subsequently performed with official hospital and death registers as the sources of data. Furthermore, specific death rates in the studied sample were compared with those in the male 40 - to 65 -year-old population in greater Stockholm. Building construction workers had a higher incidence of "violent" death than the 40 - to 65-year-old male population of greater Stockholm. Otherwise the studied workers did not differ significantly from the population with regard to causes of death. Concrete workers 51 to 61 years of age had a significantly higher incidence of myocardial infarction than other building construction workers of the same age. Concrete workers as a group were also demonstrated to differ significantly from other workers in the study with regard to many psychosocial characteristics such as childhood circumstances, education, living conditions, smoking habits, alcohol habits and financial conditions. However, the association between concrete work and myocardial infarction was demonstrated to exist even when a number of socioeconomic and psychosocial factors were held constant. Possible explanations for the association between the work situation and the incidence of myocardial infarction among the 52- to 61-year-old concrete workers are discussed.
\end{abstract}

Key words: mortality, myocardial infarction, physical effort, psychological stress

In a recent study Theorell et al. $(10,11)$ demonstrated that concrete workers aged 41-61 years had excess morbidity in myocardial infarction when compared with other building construction workers of the same age. In the same study, as well as in others, psychosocial factors were also demonstrated to be associated with a risk of the early development of myocardial infarction. For instance, the reported psychosocial work load during one

1 Department of Medicine, Serafimerlasarettet, Stockholm, Sweden

2 Laboratory for Clinical Stress Research, Karolinska Institute, Stockholm, Sweden.

3 Foundation for Industrial Safety and Health in the Construction Industry, Stockholm, Sweden.

Reprint requests to: Dr. T. Theorell, Department of Medicine, Serafimerlasarettet, Fack, 11283 Stockholm, Sweden. year was demonstrated to be associated with an elevated risk of myocardial infarction during two years of follow-up (11). The present study is focused on the interplay between psychosocial and socioeconomic variables on one hand and concrete work on the other, the main question to be answered being "Does concrete work have an independent association with the risk of myocardial infarction or could the association be explained by socioeconomic and psychosocial characteristics of the concrete workers as a group?"

\section{MATERIAL AND METHODS}

All the male members of the union of building construction workers $(\mathrm{N}=8,973)$ between 41 and 61 years of age in September of 1972 were invited to participate in 


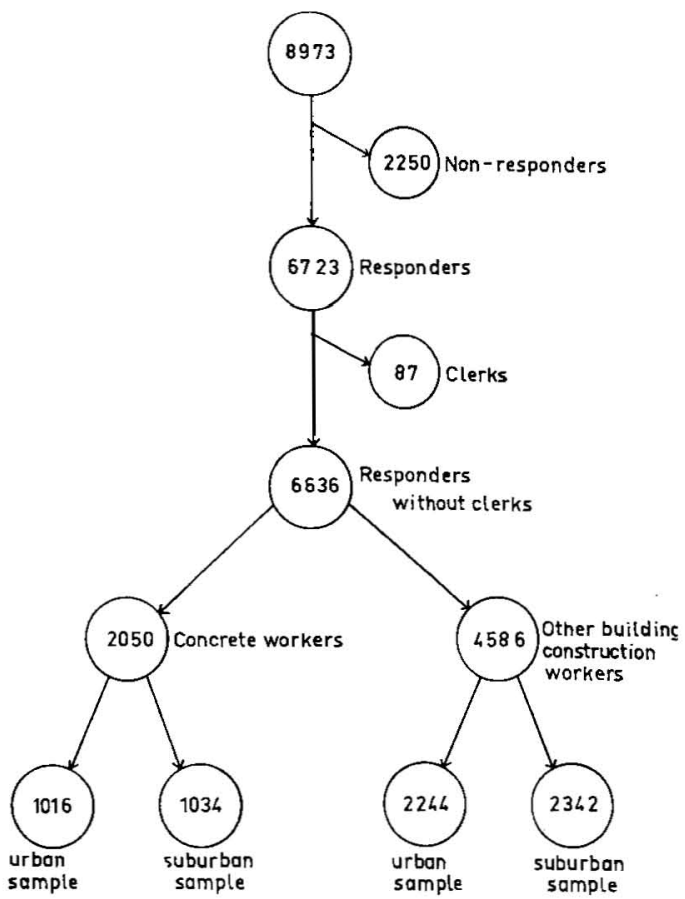

Fig. 1. The total target population in relation to the groups studied.

the study. A questionnaire with about 60 questions concerning life events which had taken place during the last year, as well as a number of psychological and social characteristics, was sent out in September 1972. Those who did not respond initially were reminded to do so, and this procedure was repeated once. Twenty-five per cent did not respond. Out of the 6,723 respondents 87 clerks were excluded from the study. In September 1972 there were 2,050 men classified as concrete workers according to the union; 4,586 belonged to other categories. In the present study these groups have been further divided into those living in the urban and those living in the suburban part of the greater Stockholm area (fig. 1).

The following registers were used in the mortality and morbidity follow-up of the respondents: (a) the central register of all deaths (Statistiska Centralbyrån) and (b) the register of all hospitalizations in the greater Stockholm area.

The causes of death were recorded from the former and all relevant hospital records and autopsy reports were examined. The latter was used in the search for cases who had been under care for myocardial infarction at any of the hospitals in greater Stockholm. All hospital records were examined. The follow-up period for myocardial infarction and coronary death was September 1972 - December 1974, whereas the follow-up period for causes of death other than coronary was September 1972 - December 1973.

\section{Statistics}

The total mortality of the studied building construction workers was compared with that of the total 40- to 65-year-old male population in greater Stockholm (Statistiska Centralbyrån). The official statistics for this population are available for 5-year cohorts. The 40- to 65-year-old cohorts most closely matched the age of the studied workers, the median age of the studied workers after the first half of the period of follow-up being 52 years and the corresponding theoretical age for the comparison population being 52.5 years. A comparison was also made for other causes of death, namely, cancer, "violent" and cardiac death. Single psychosocial variables were compared between concrete workers and other building construction workers.

For the significance testing of differences observed in the previously mentioned analyses, $\mathrm{Z}$ scores were computed. One-tailed tests were used in the analysis of mortality and morbidity. Building construction workers were hypothesized to have higher mortality and illness rates than the male population in greater Stockholm in the same age group. Concrete workers were hypothesized to have higher mortality and illness rates than other building construction workers. Two-tailed tests were used in the analysis of single psychosocial items, however, since no directional hypothesis could be stated for most of the comparisons.

\section{Cross-tabulations}

Relevant psychosocial variables were dichotomized. Thus the whole population was divided into those with and those without a specific psychosocial item. The association between concrete work and 
Table 1. Prevalence $(\%)$ of the single items included in the psychosocial work load index for the total study group.

\begin{tabular}{lc}
\hline Item $^{\mathrm{a}}$ & $\begin{array}{c}\text { Total study group } \\
\text { ( } \mathrm{n}=5,187)\end{array}$ \\
\hline & 1.3 \\
Change of profession & 4.6 \\
Extra job & 4.1 \\
Starting of extra job & 4.3 \\
End of extra job & 3.4 \\
Change of work hours & 10.2 \\
Increased responsibility & 1.9 \\
Decreased responsibility & 3.3 \\
Too little or somewhat too little & \\
job responsibility & 12.5 \\
Too much or somewhat too much & 5.2 \\
job responsibility & 3.7 \\
Problems with superiors & \\
Problems with work mates & 14.3 \\
Unemployed for more than 30 & \\
consecutive days &
\end{tabular}

a All items concerned the $\mathbf{1 2}$ months preceding the study.

incidence of myocardial infarction was then analyzed for both groups, the one with and the one without the item. The variables included in this analysis were the following: 1: age (older than 51 years); 2: "background index" (number of siblings at least 6 and/or grown up in broken home before age 15); 3 : cigarette smoking (cigarette smoker during the last 12 months); 4: psychosocial work load ("loaded" with at least one of the single items included in table 1); 5: crowdedness index (number of members of household exceeding that of the number of rooms); 6 : income (sick pay more than 51 Swedish crowns/day); and 7: profession (concrete work).

After each single psychosocial loading factor had been analyzed in relation to the association between concrete work and myocardial infarction, the older half of the studied sample was subjected to an analysis of the effect of several concomitant psychosocial loading factors upon the association between concrete work and myocardial infarction. For this analysis, variables $2,3,4,5$, and 6 were used. The 2 -year incidence of myocardial infarction among 51- to 61-year-old concrete workers versus that of other 51- to 61-year-old building construction workers was computed among those "loaded" with none or one of the factors, as well as among those with two, three, and four or five factors, respectively.

Finally, the seven dichotomized variables were used as "independent" variables in a multiple regression equation aimed at predicting the risk of myocardial infarction. The utilized program was constructed for nonparametric dichotomized variables. The relative importance of each factor in relation to myocardial infarction risk was expressed as a "beta" coefficient, i.e., as the "standardized" regression coefficient. The statistical significance of the equation was tested by means of variance analysis (4).

\section{RESULTS}

Fig. 2 demonstrates that among 52- to 61 year-old concrete workers there is an elevated risk of having a myocardial infarction when these subjects are compared with age-matched building construction workers $(p<0.05)$. The risk is more accentuated when the analysis is confined only to survivors of myocardial infarction $(\mathrm{p}<0.005)$.

Table 2 shows the rates of other causes of death in the total male 40- to 65-yearold population in greater Stockholm as compared with those of the building construction workers. As expected, the building construction workers as a group had a higher rate of "violent" death than did other age-matched males in Stockholm (2.11 \%/year as compared with $1.37 \%$ / year, $\mathrm{p}<0.05$ ). Otherwise no significant differences were demonstrated. There were no significant differences between concrete workers and other building construction workers with regard to rates of specific causes of death, except that concrete workers had a slightly lower risk of death from cancer than other building construction workers $(0.1 \% /$ year versus $0.4 \%$ year, $\mathrm{p}<0.05)$.

For the older (52-61 years) and the younger (41-51 years) halves of the studied group fig. $3 \mathrm{~A}$ and $\mathrm{B}$ show which psychosocial variables differentiated significantly between the concrete workers and the other building construction workers. Twenty-four variables were discriminative for the older half and 25 for the younger half. The most highly significantly dis- 

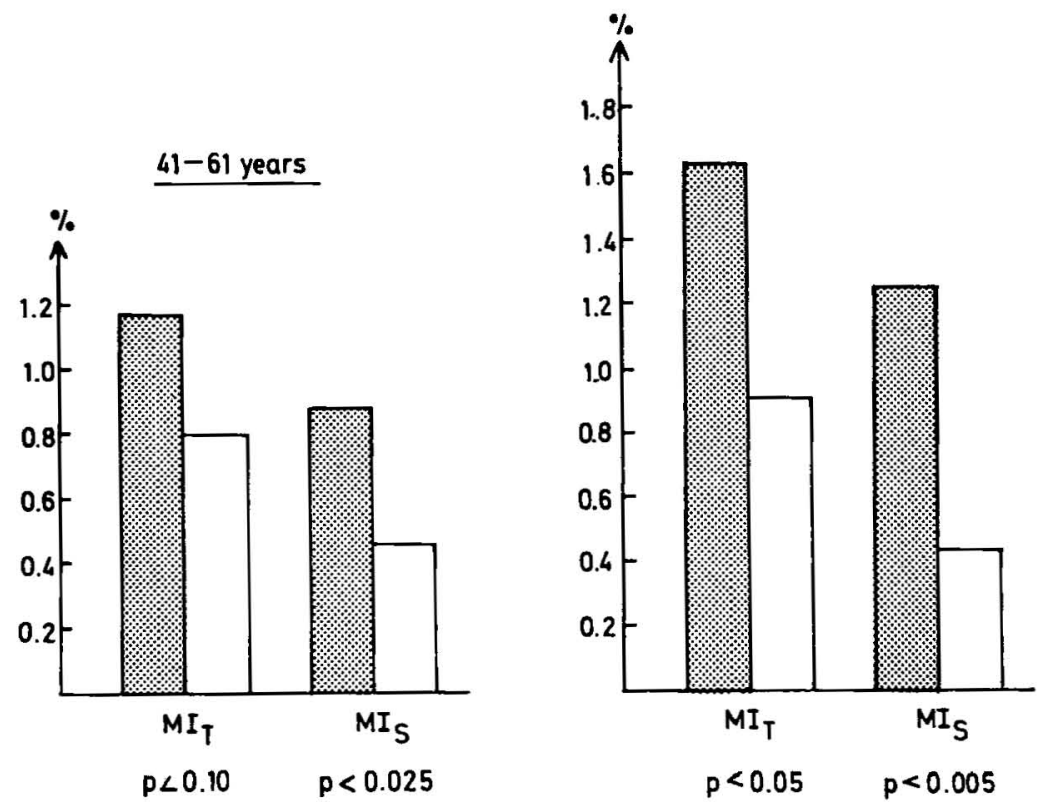

Fig. 2. Incidence of myocardial infarction in relation to concrete work. $\left(\mathrm{MI}_{\mathrm{T}}=\right.$ deaths and survivals, $\mathrm{MIS}_{\mathrm{S}}=$ survivals only, $\%=$ number of cases $/ 100$ subjects $/ 2$ years of follow up)

Table 2. Specific causes of death among building construction workers and among the ageadjusted male population in greater Stockholm.

\begin{tabular}{|c|c|c|c|c|}
\hline \multirow[t]{2}{*}{$\begin{array}{l}\text { Cause of } \\
\text { death }\end{array}$} & \multicolumn{2}{|c|}{$\begin{array}{l}\text { Total male population } \\
40-65 \text { years of age } \\
(\mathrm{N}=215,772)\end{array}$} & \multicolumn{2}{|c|}{$\begin{array}{l}\text { Male building construction workers } \\
41-61 \text { years of age } \\
\qquad(\mathrm{N}=8,973) \\
\text { Means for the years } 1973-74\end{array}$} \\
\hline & Number of deaths & Deaths/1,000/year & Number of deaths & Deaths/1,000/year \\
\hline Cancer & 482 & 2.23 & 15.5 & $1.72^{+}$ \\
\hline "Violent" death & 295 & 1.37 & 19 & $2.11^{*}$ \\
\hline Cardiac death & 601 & 2.79 & 27.5 & $3.06+$ \\
\hline Other & 629 & 2.92 & 18 & $2.00^{+}$ \\
\hline
\end{tabular}

+ Not significant.

* $\mathrm{Z}=1.90, \mathrm{p}<0.05$.

criminative item in both age groups was education. Thus the concrete workers were more likely than other building construction workers to have gone through primary school only. Other background factors which were much more common in the concrete worker group were (a) having grown up with many siblings $(\geqslant 6)$ and $(b)$ having grown up in a broken home. The latter of these two factors was not discriminative in the younger half and the former less significantly so in the younger than in the older half of the studied sample.

The older concrete workers had divorced parents before they reached the 


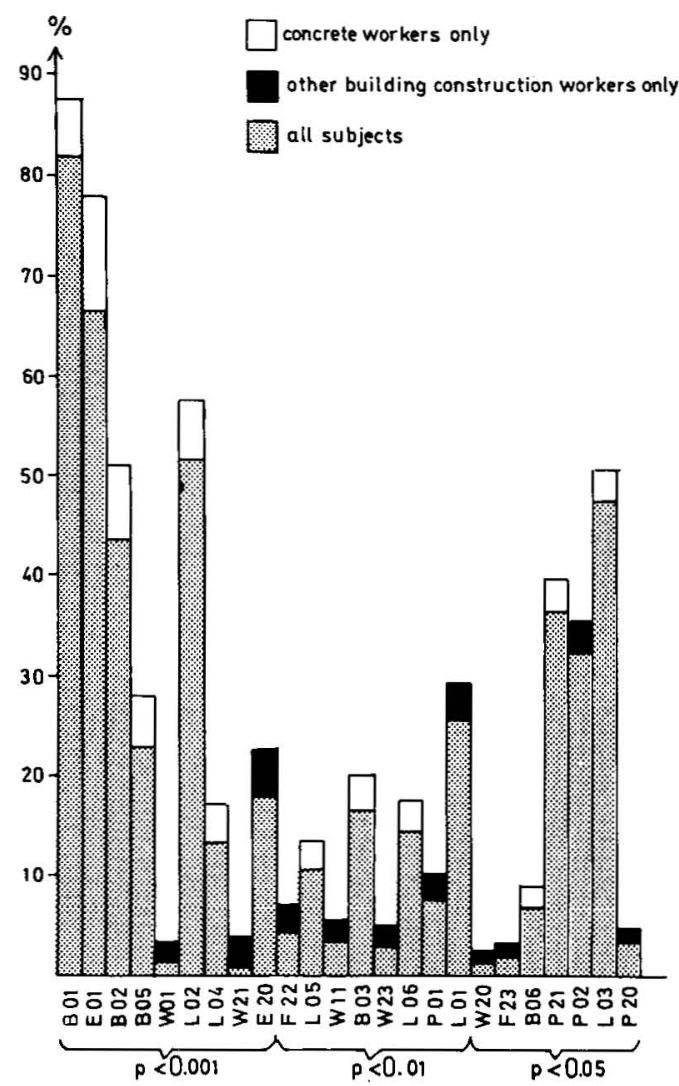

A: Those $52-61$ years of age

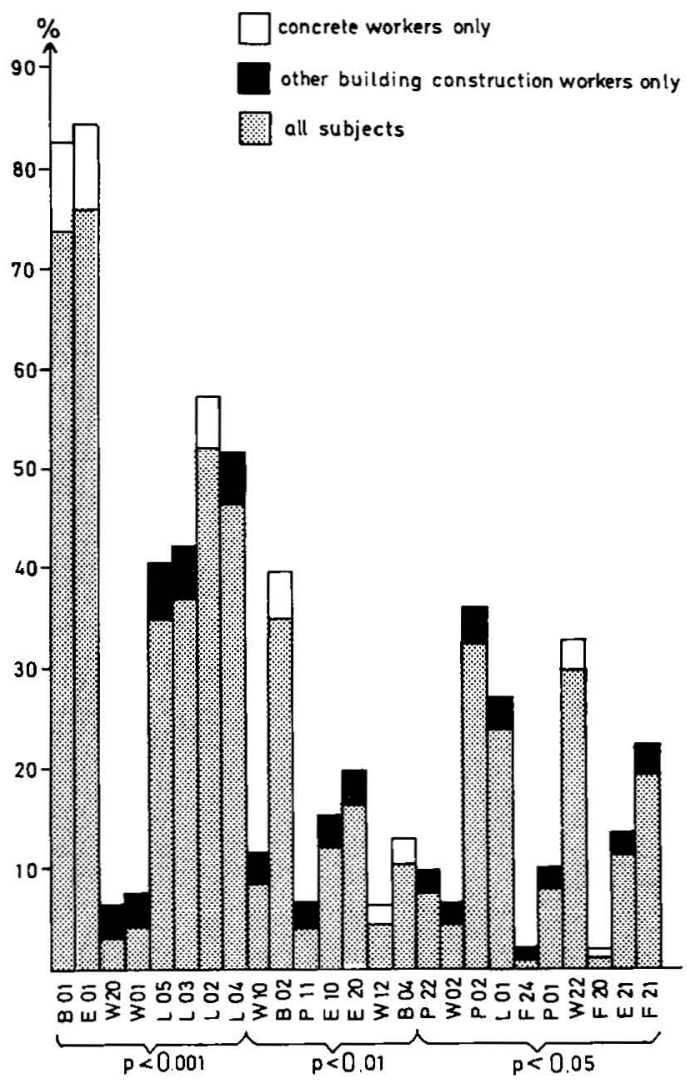

B: Those $41-51$ years of age

Fig. 3. Psychosocial items which significantly differentiated between the concrete workers and other building construction workers.

age of 15 or had grown up as illegitimate children more frequently than other older workers studied. Furthermore, the 52- to 61-year-old concrete workers had changed residence at least 10 times after the age of 15 to a greater extent than other 52- to 61year-old building construction workers, but there was no difference among the younger subjects. The concrete workers lived in rented apartments rather than in houses of their own more frequently than others. The other variables indicating living standard showed a pattern which was difficult to interpret, and they have been collected into the "crowdedness" index.

With regard to work conditions, concrete workers - both the younger and the older ones - claimed that they worked overtime less frequently than the other workers.

The younger concrete workers had been unemployed during at least 30 consecutive days during the preceding year to a greater extent than the other younger building construction workers, but the older ones had not. Retirement among older subjects during the preceding year had been more common among other building construction workers than among concrete workers.

With regard to financial conditions, the item "having a sick leave pay of more or less than 48 Swedish crowns/day" indicated that concrete workers had a good official regular income more frequently than others.

Both in the younger and the older 
Work conditions (W)

W01: Average number of work hours/week on average $\geqslant 50$ during the preceding 12 months

W02: Presently holding an extra job

W10: Somewhat too much responsibility during the preceding 12 months

W11: Problems with superiors during the preceding 12 months

W12: Poor satisfaction with the job during the preceding 12 months

W20: Started extra job during the preceding 12 months

W21: Stopped extra job during the preceding 12 months

W22: "Other" important change in the work situation during the preceding 12 months

W23: Retirement during the preceding 12 months

Economy (E)

E01: Sick pay $\geqslant 48$ Swedish crowns/day

E10: Better financial state than most relatives and friends

E20: Decreased income during the preceding 12 months

E21: Mortgage or loan exceeding 10,000 Swedish crowns during the preceding 12 months

\section{Living conditions (L)}

L01: Living in own house

L02: Living in rented apartment

L03: Living in two rooms or less

L04: One or more children below 17 years of age in the household

L05: Three or more family members in the household

L06: Changed residence 10 times or more since age 15

Key to variables in fig. 3.

groups, teetotalers and nonsmokers were less common among concrete workers than among other building construction workers.

The younger concrete workers claimed that they had a better financial state than average friends or relatives less frequently than other age-comparable building construction workers. This did not apply to the older concrete workers.

\section{Cross-tabulation}

Table 3 shows the incidence of myocardial infarction, with certain other factors held
Family $(F)$

F20: Acquired child (own or adopted) during the preceding 12 months

F21: Close relative seriously ill during the preceding 12 months

F22: Spouse stopped salaried employment during the preceding 12 months

F23: Serious conflict with spouse during the preceding 12 months

F24: Married or started cohabitation during the preceding 12 months

Personal habits $(P)$

P01: Teetotaler during the preceding 12 months

P02: Nonsmoker during the preceding 12 months

P03: Having had a hobby during the preceding 12 months

P10: Physically more passive than most agecomparable friends

P11: Somewhat more energetic than agecomparable friends

P20: Physically more active than 12 months ago

P21: Decreased alcohol consumption during the preceding 12 months

P22: Major change in sexual habits during the preceding 12 months

\section{Background (B)}

B01: Primary school only

B02: Grew up with 6 siblings or more

B03: Father and/or mother died before subject reached the age of 15

B04: Grew up as the seventh or higher number among siblings

B05: Did not live with both biological parents until age 15

B06: Parents divorced before subject reached 15 years of age or subject illegitimately born

constant among concrete workers, divided by that among other building construction workers. The analysis has been performed for all cases of myocardial infarction and for the survivors only. The variables psychosocial work load, cigarette smoking and crowdedness did not affect the association between concrete work and risk of myocardial infarction. The association between concrete work and risk of myocardial infarction was observed only in the older half of the studied sample and was stronger among those with a high level of sick pay ( $\geqslant 51$ Swedish crowns) and among those who had grown up in a broken home and/or with many siblings. 
Table 3. Association between concrete work and myocardial infarction when other factors were held constant.

\begin{tabular}{|c|c|c|c|c|c|c|c|}
\hline \multirow[b]{2}{*}{$\begin{array}{l}\text { No. of } \\
\text { con- } \\
\text { crete } \\
\text { work- } \\
\text { ers }\end{array}$} & \multirow[b]{2}{*}{$\begin{array}{l}\text { No. of } \\
\text { other } \\
\text { building } \\
\text { con- } \\
\text { struc- } \\
\text { tion } \\
\text { workers }\end{array}$} & \multicolumn{2}{|c|}{$\begin{array}{l}\text { Concrete } \\
\text { workers }\end{array}$} & \multicolumn{2}{|c|}{$\begin{array}{c}\text { Other building } \\
\text { construction } \\
\text { workers }\end{array}$} & \multirow[b]{2}{*}{$\begin{array}{c}\text { Ratio } \\
\text { ob- } \\
\text { served } \\
\text { to ex- } \\
\text { pected }\end{array}$} & \multirow[b]{2}{*}{$\begin{array}{c}\text { Z-value } \\
\text { for } \\
\text { differ- } \\
\text { ence of } \\
\text { propor- } \\
\text { tions }\end{array}$} \\
\hline & & $\begin{array}{c}\text { No. of } \\
\text { cases }\end{array}$ & $\begin{array}{c}\text { Inci- } \\
\text { dence } \\
\text { (cases/ } \\
100 \\
\text { subjects/ } \\
2 \text { years) }\end{array}$ & $\begin{array}{l}\text { No. of } \\
\text { cases }\end{array}$ & $\begin{array}{c}\text { Inci- } \\
\text { dence } \\
\text { (cases/ } \\
100 \\
\text { subjects/ } \\
2 \text { years) }\end{array}$ & & \\
\hline
\end{tabular}

All cases of myocardial infarction

\begin{tabular}{|c|c|c|c|c|c|c|c|c|}
\hline All subjects & 2,050 & 4,586 & 24 & 1.2 & 37 & 0.8 & 1.50 & $1.58^{\circ}$ \\
\hline $\begin{array}{l}\text { Psychosocial } \\
\text { work load } \\
\text { No psychosocial }\end{array}$ & 529 & 1,383 & 10 & 1.9 & 14 & 1.0 & 1.90 & $1.59^{\circ}$ \\
\hline work load & 1,521 & 3,203 & 14 & 0.9 & 23 & 0.7 & 1.29 & 0.73 \\
\hline $\begin{array}{l}>51 \text { years } \\
\leq 51 \text { years }\end{array}$ & $\begin{array}{l}1,041 \\
1,009\end{array}$ & $\begin{array}{l}2,299 \\
2,287\end{array}$ & $\begin{array}{r}17 \\
7\end{array}$ & $\begin{array}{l}1.6 \\
0.7\end{array}$ & $\begin{array}{l}21 \\
16\end{array}$ & $\begin{array}{l}0.9 \\
0.7\end{array}$ & $\begin{array}{l}1.78 \\
1.00\end{array}$ & $1.78^{*}$ \\
\hline $\begin{array}{l}\text { Smokers } \\
\text { Nonsmokers }\end{array}$ & $\begin{array}{r}1,342 \\
708\end{array}$ & $\begin{array}{l}2,823 \\
1,763\end{array}$ & $\begin{array}{r}17 \\
7\end{array}$ & $\begin{array}{l}1.3 \\
1.0\end{array}$ & $\begin{array}{l}26 \\
11\end{array}$ & $\begin{array}{l}0.9 \\
0.6\end{array}$ & $\begin{array}{l}1.44 \\
1.67\end{array}$ & $\begin{array}{l}1.19 \\
1.07\end{array}$ \\
\hline $\begin{array}{l}\text { Favorable } \\
\text { background } \\
\text { Unfavorable }\end{array}$ & 1,263 & 2,514 & 18 & 1.4 & 22 & 0.9 & 1.56 & $1.40^{\circ}$ \\
\hline background & 787 & 2,072 & 6 & 0.8 & 15 & 0.7 & 1.14 & 0.28 \\
\hline $\begin{array}{l}\text { Apartment } \\
\text { small for family } \\
\text { Apartment not }\end{array}$ & 747 & 1,630 & 10 & 1.3 & 16 & 1.0 & 1.30 & 0.67 \\
\hline small for family & 1,303 & 2,956 & 14 & 1.1 & 21 & 0.7 & 1.57 & $1.34^{\circ}$ \\
\hline $\begin{array}{l}\text { Sick leave pay } \\
<51 \text { Scr. } \\
\text { Sick leave pay }\end{array}$ & 760 & 2,188 & 7 & 0.9 & 20 & 0.9 & 1.00 & 一 \\
\hline$\geq 51$ Ser. & 1,290 & 2,398 & 17 & 1.3 & 17 & 0.7 & 1.86 & $1.82 *$ \\
\hline
\end{tabular}

Survivers of myocardial infarction only

\begin{tabular}{|c|c|c|c|c|c|c|c|c|}
\hline All subjects & 2,050 & 4,586 & 18 & 0.9 & 21 & 0.5 & 1.80 & $1.93^{*}$ \\
\hline $\begin{array}{l}\text { Psychosocial } \\
\text { work load } \\
\text { No psychosocial } \\
\text { work load }\end{array}$ & 529 & 1,383 & 10 & 1.5 & 12 & 0.9 & 1.67 & 1.14 \\
\hline $\begin{array}{l}>51 \text { years } \\
\leq 51 \text { years }\end{array}$ & $\begin{array}{l}1,041 \\
1,009\end{array}$ & $\begin{array}{l}2,299 \\
2,287\end{array}$ & $\begin{array}{r}13 \\
5\end{array}$ & $\begin{array}{l}1.2 \\
0.5\end{array}$ & $\begin{array}{l}10 \\
11\end{array}$ & $\begin{array}{l}0.4 \\
0.5\end{array}$ & $\begin{array}{l}3.00 \\
1.00\end{array}$ & $\underbrace{2.66^{\S}}$ \\
\hline $\begin{array}{l}\text { Smokers } \\
\text { Nonsmokers }\end{array}$ & $\begin{array}{r}1,342 \\
708\end{array}$ & $\begin{array}{l}2,823 \\
1,763\end{array}$ & $\begin{array}{r}13 \\
5\end{array}$ & $\begin{array}{l}1.0 \\
0.7\end{array}$ & $\begin{array}{r}15 \\
6\end{array}$ & $\begin{array}{l}0.5 \\
0.3\end{array}$ & $\begin{array}{l}2.00 \\
2.33\end{array}$ & $\begin{array}{l}1.86^{*} \\
1.38^{\circ}\end{array}$ \\
\hline $\begin{array}{l}\text { Favorable } \\
\text { background } \\
\text { Unfavorable } \\
\text { background }\end{array}$ & $\begin{array}{r}1,263 \\
787\end{array}$ & 2,514 & 15 & 1.2 & 14 & 0.3 & 2.00 & $\begin{array}{l}1.95^{*} \\
0.41\end{array}$ \\
\hline $\begin{array}{l}\text { Apartment small } \\
\text { for family } \\
\text { Apartment not } \\
\text { small for family }\end{array}$ & 1,303 & 1,630 & 12 & 0.8 & 10 & 0.6 & 1.33 & $\begin{array}{l}0.57 \\
2.04^{+}\end{array}$ \\
\hline $\begin{array}{l}\text { Sick leave pay } \\
<51 \text { Scr. } \\
\text { Sick leave pay } \\
\geq 51 \text { Scr. }\end{array}$ & 1,290 & 2,188 & 12 & 0.8 & 10 & 0.5 & 1.60 & $\begin{array}{l}0.93 \\
1.45^{\circ}\end{array}$ \\
\hline
\end{tabular}

One-tailed Z-test: ${ }^{\circ} \mathrm{p}<0.10 ; * \mathrm{p}<0.05 ;+\mathrm{p}<0.025 ; \S \mathrm{p}<0.005$. 
Table 4. Incidence of myocardial intarction (MI) for the 52- to 61-year-ola concrete workers and other building construction workers in relation to the number of psychosocial risk items.

\begin{tabular}{|c|c|c|c|c|c|c|c|c|c|c|}
\hline \multirow[b]{2}{*}{$\begin{array}{l}\text { No. of } \\
\text { risk } \\
\text { items }\end{array}$} & \multicolumn{5}{|c|}{ Concrete workers } & \multicolumn{5}{|c|}{ Other building construction workers } \\
\hline & $\begin{array}{l}\text { No. of } \\
\text { sub- } \\
\text { jects }\end{array}$ & $\begin{array}{c}\text { Total } \\
\text { no. of } \\
\text { MI } \\
\text { cases }\end{array}$ & $\begin{array}{c}\text { Inci- } \\
\text { dence } \\
\text { (cases/ } \\
100 \\
\text { sub- } \\
\text { jects/ } \\
2 \text { years) }\end{array}$ & $\begin{array}{l}\text { No. of } \\
\text { MI } \\
\text { surviv- } \\
\text { ers }\end{array}$ & $\begin{array}{c}\text { Inci- } \\
\text { dence } \\
\text { (cases/ } \\
100 \\
\text { sub- } \\
\text { jects/ } \\
2 \text { years) }\end{array}$ & $\begin{array}{l}\text { No. of } \\
\text { sub- } \\
\text { jects }\end{array}$ & $\begin{array}{l}\text { Total } \\
\text { no. of } \\
\text { MI } \\
\text { cases }\end{array}$ & $\begin{array}{c}\text { Inci- } \\
\text { dence } \\
\text { (cases/ } \\
100 \\
\text { sub- } \\
\text { jects/ } \\
2 \text { years) }\end{array}$ & $\begin{array}{l}\text { No. of } \\
\text { MI } \\
\text { surviv- } \\
\text { ers }\end{array}$ & $\begin{array}{c}\text { Inci- } \\
\text { dence } \\
\text { (cases/ } \\
100 \\
\text { sub- } \\
\text { jects/ } \\
2 \text { years) }\end{array}$ \\
\hline $0-1$ & 268 & 3 & 1.12 & 3 & 1.12 & 598 & 5 & 0.84 & 2 & 0.33 \\
\hline 2 & 353 & 4 & 1.13 & 2 & 0.57 & 741 & 5 & 0.67 & 2 & 0.27 \\
\hline 3 & 293 & 6 & 2.05 & 4 & 1.37 & 651 & 5 & 0.77 & 2 & 0.31 \\
\hline $4-5$ & 127 & 4 & 3.15 & 4 & 3.15 & 309 & 6 & 1.94 & 4 & 1.29 \\
\hline
\end{tabular}

\section{Multiple psychosocial risk factors}

Table 4 shows the 2-year incidence of myocardial infarction among concrete workers and other building construction workers in the older age group (52-61 years) in relation to the number of psychosocial risk items. At all levels, the concrete workers had a higher incidence of both total myocardial infarction and of survival of myocardial infarction. The table also indicates that concrete workers in the category with 4-5 psychosocial risk items have a four times higher risk of developing myocardial infarction than building construction workers in the nonconcrete worker category with only $0-1$ psychosocial risk factors.

Tables 5 and 6 show the results of the multiple regression analysis. For the variable total myocardial infarction (Table 5 ), the three best predictors were age above $51 \quad(\beta=0.027)$, psychosocial work load ( $\beta=0.024)$ and concrete work $(\beta=$ 0.017). For the variable survival of myocardial infarction the three best predictors were psychosocial work load $(\beta=$ $0.040)$, concrete work $(\beta=0.024)$ and unfavorable background $(\beta=0.023)$.

\section{DISCUSSION}

The main conclusion to be drawn from the present study is that concrete work is associated with risk of myocardial infarction between the ages of 52 and 61 and that this association is partly independent
Table 5. Multiple regression analysis of seven risk factors in relation to the total number of cases of myocardial infarction.

\begin{tabular}{lc}
\hline Variable & $\begin{array}{c}\text { Standardized } \\
\text { regression } \\
\text { coefficient }(\beta)\end{array}$ \\
\hline Age > 51 years & 0.027 \\
Psychological work load & 0.024 \\
Concrete work & 0.017 \\
Apartment small for family & 0.017 \\
Unfavorable background & 0.013 \\
Cigarette smoking & 0.013 \\
Sick leave pay $>51$ Scr. & 0.003 \\
\hline
\end{tabular}

$F=1.98, \mathrm{df}=7 />6,000, \mathrm{p}<0.10$.

Table 6. Multiple regression analysis of seven risk factors in relation to survival after myocardial infarction.

\begin{tabular}{lc}
\hline Variable & $\begin{array}{c}\text { Standardized } \\
\text { regression } \\
\text { coefficient }(\beta)\end{array}$ \\
\hline Psychosocial work load & 0.040 \\
Concrete work & 0.024 \\
Unfavorable background & 0.023 \\
Age > 51 years & 0.016 \\
Cigarette smoking & 0.011 \\
Apartment small for family & 0.009 \\
Sick leave pay > 51 Scr. & 0.006 \\
\hline
\end{tabular}

$\mathrm{F}=3.09, \mathrm{df}=7 />6,000, \mathrm{p}<0.01$.

of socioeconomic and psychosocial factors that are unrelated to work. The findings did not apply to concrete workers below the ages of 41 and 51 however. The differ- 
ence in relative risk between concrete workers above and below 51 years of age, respectively, may be interpreted in the following two ways: (a) Some factor in the existing work situation may have precipitated more myocardial infarctions among the older concrete workers than among the others, despite a similar extent of coronary atherosclerosis, a condition underlying the majority of myocardial infarctions, in both groups; (b) coronary atherosclerosis may have been accelerated more in the older group of concrete workers than among the other subjects studied.

Results of an interview study now in progress show that the present psychosocial work environment of concrete workers can be considered similar to that of other building construction workers although building construction workers still consider concrete work of today to be physically more demanding than other kinds of building construction. Potentially significant toxicological factors are unknown. Thus heavy physical load in the present work situation may be partly responsible for the excess incidence of myocardial infarction among the 52- to 61-year-old concrete workers.

Interviews of building construction workers show that concrete work in the 1940 s and 1950s was extremely demanding physically, and it involved very heavy repetitive work. Furthermore, during the 50 s the piecework salary arrangement caused time pressure. According to Gardell (2) the combination of boring work and time pressure is particularly harmful from the psychological point of view. The combination of heavy physical repetitive effort with psychological pressure, which was more intensive and more frequent for the group of concrete workers than for other building construction workers, may be particularly dangerous for the cardiovascular system because of frequently elevated blood pressure $(1,8)$. The importance of elevated blood pressure in the etiology of atheroschlerosis is well documented (7). In the present study, however, we had the opportunity of studying the health survey data of a representative subsample of 194 men. In this group the casual systolic and diastolic blood pressure levels did not differentiate concrete workers from other building construction workers. Therefore, the association between concrete work and myocardial infarction may not be mediated by hypertensive illness. Nevertheless, repeated blood pressure elevations during the workday may be important in the pathogenesis.

To our knowledge there are no published studies available in which exposure to many years of repetitive, heavy physical effort has been studied in relation to manifestations of coronary heart disease. Most of the published studies in this field make no distinction between different kinds of physical effort.

Another difficulty involved in the interpretation of studies on physical activity in relation to the incidence of manifestations of coronary artery disease is that subjects who develop symptoms tend to abandon physically demanding occupations. This was not the case in the present study but such a situation may have biased the results against any association between physically strenuous work and the incidence of coronary heart disease in several studies. Autopsy results from 40to 59-year-old males who had died in accidents indicated that the subjects with strenuous work had the same prevalence of lesions in the coronary arteries as subjects with sedentary and moderately demanding occupations (5). Further studies are needed on this subject.

During the latter part of the 1950s, the disappearance of several manual components of concrete work created a situation in which the physical effort of this group was less demanding. The lack of difference in myocardial infarction incidence between the 41- to 51-year-old concrete workers and the other building construction workers could be explained partly by this improvement.

It is known that the recruitment of concrete workers was different 20 years ago. At that time a small amount of skill was required for concrete work, and mainly uneducated men whose families could not provide financial support for education to more skilled work were employed in these jobs. This situation is also reflected in the data of the present study. The older concrete workers often grew up in large families and/or in broken homes and were relatively uneducated as a group. As pointed out by Hinkle, social background 
has strong effects on personal habits throughout life (3). As an illustration there was a low percentage of nonsmokers and nondrinkers among older concrete workers. On the other hand it should be pointed out that all members of the group of concrete workers in the studied population had been classified as "skilled workers" by the union. They had all qualified by taking special courses or by illustrating good occupational skill.

The apparent discrepancy between the high average official income on one hand and the low average number of work hours per week and the low rate of extra jobs and subjective financial satisfaction on the other, both of which characterized the concrete workers, may be explained by the concrete workers' few opportunities to take nontaxed extra jobs during their leisure time. Such a practice is common among plumbers, carpenters, and several other specialized building construction workers.

The effect of alcohol habits on the incidence of myocardial infarction has been discussed in the literature (9) but could not be analyzed in depth in the present study.

The discrepancy between the associations between concrete work and the survival of a myocardial infarction on one hand and between concrete work and coronary death on the other may be explained by the favorable effect of previous physical activity on prognosis during the course of a myocardial infarction (6).

The multivariate analyses showed that concrete work did have an effect on myocardial infarction risk when several other variables were held constant. Thus background characteristics, smoking habits and several other variables did not explain all of the association between concrete work and myocardial infarction among older subjects. The combination of strenuous repetitive physical effort with a rushed tempo, which has been characteristic of concrete work, may account for part of the difference.

\section{ACKNOWLEDGMENT}

The present study was supported by grants from the Swedish National Association against Heart and Lung Diseases and by the Swedish Council for Building Research.

\section{REFERENCES}

1. FRANKENHAEUSER, M., POST, B., NORDHEDEN, B. and SJÖBERG, H. Physiological and subjective reactions to different physical work loads. Percept. mot. skills 28 (1969) 343-349.

2. GARDELL, B. Alienation and mental health in the modern industrial environment. In: L. LEVI (ed.), Society, stress and disease (vol. I. Psychosocial environment and psychosomatic diseases). Oxford University Press, London, 1971, pp. 148-180.

3. HINKLE, L. E., JR. The effect of culture change, social change and changes in interpersonal relationships on health. In: B. S. DOHRENWEND and B. P. DOHRENWEND (eds.), Stressful life events Their nature and effects. John Wiley and Sons, New York, N.Y. 1974, pp. 9-44.

4. HOPE, K. Methods of multivariate analysis. University of London Press, London, 1968. 288 p.

5. KAGAN, A. Atherosclerosis and myocardial disease in relation to physical activity of occupation. Bull. W. H. O. 53 (1976) 615622.

6. KANNEL, W. B., SORLIE, P. and MC NAMARA, $P$. The relation of physical activity to risk of coronary heart disease: The Framingham study. In: O. ANDREE LARSEN and R. O. MALMBORG (eds.), Coronary heart disease and physical fitness. Munksgaard, Copenhagen, 1971, pp. $256-260$.

7. KEYS, A., ARAVANIS, C., BLACKBURN, H., VAN BUCHEN, F. S. P., BUZINA, R., DJORDJEVIC, B. S., FIDANZA, F., KARVONEN, M. J., MENOTTI, A., PUDDU, V. and TAYLOR, H. Probability of middleaged men developing coronary heart disease in five years. Circulation 45 (1972) $815-828$.

8. KILBOM, A. Circulatory adaptation during static muscular contractions - A review. Scand. j. work environ. \& health 2 (1976) $1-13$

9. MYRHED, M. Alcohol consumption in relation to factors associated with ischemic heart disease: A co-twin control study. Acta med. scand. (1974): suppl 567. 93 p.

10. THEORELL, T., LIND, E. and FLODERUS, B. The relationship of disturbing life changes and emotions to the early development of myocardial infarction and some other serious illnesses. Int. $j$. epidemiol. 4 (1975) 281-293.

11. THEORELL, T. and FLODERUS-MYRHED, B. "Work load" and myocardial infarction - A prospective psychosocial analysis. Int. j. epidemiol. 6 (1977) $17-21$.

Received for publication: 1977-02-28 